V. Telvak

\section{CULTURAL POLITICS OF MYKHAILO HRUSHEVSKY AS AN EDITOR OF VILLAGE MAGAZINES}

The article is dedicated to the reconstruction of cultural politics of Mykhailo Hrushevsky as an editor and author of magazines "Selo» and "Zasiv». It has been proved that the fight against illiteracy of peasants was a priority task for M. Hrushevsky as an editor. An emphasis has been put on the fact that M. Hrushevsky was encouraging peasants for obtaining education as well as he was highlighting the need for bringing up the Ukrainian readership.

As it has been investigated, M. Hrushevsky invested efforts in formation of political culture of his reader. He was consistently putting forward the advantages of autonomous form of state organization regarding political tasks of Ukrainians in Russian Douma. However, it has been noted, that M. Hrushevsky was not imposing his own political preferences, but rather pointed on the need of taking into account the national interests.

It has been clarified, that the historical component of culture was of significant importance for M. Hrushevsky. His historical ideology can be traced in his texts, focused on historical personalities, memorials and events. The main goal of his historical journalism was to give his readers the feeling of unity of Ukrainian lands. His texts were abundantly illustrated which certainly influenced the enlightment function of his works.

The reception of his work in village magazines was investigated as well. Both representatives of intelligentsia and peasantry gave excited feedbacks about his editing in the abovementioned journals'. However, this excitement led to increasing popularity of these magazine, which was noticed by tsar censorship and eventually led to a halt of their publication.

The conclusion emphasizes on the objectivity and diligence of the historian in discussion of important questions. What was even more important is that he avoided the moralizing rhetoric's in his writings. The peasants highly appreciated the models of modern Ukrainians and Ukraine (e.g. the ideal of united Ukraine) designed by M. Hrushevsky. It has been proved, that this made magazines the school of national upbringing and led to the popularity of these magazines in broad reader circles.

Key words: M. Hrushevsky, cultural politics, publicistic works, «Selo», «Zasiv».

УДК 94: 327.2(470:477)(045)

DOI: $10.31651 / 2413-8142-2018-19-134-137$

А.Ю. Чабан

доктор історичних наук, професор, професор кафедри археології та спеціальних галузей історичної науки Черкаського начіонального університету імені Богдано

Хмельнииького

\section{ВИТОКИ ТА ШЛЯХИ РОЗВИТКУ ІМПЕРСЬКОЇ ПОЛІТИКИ РОСІЇ ЩОДО УКРАЇНИ}

У запропонованій статті проаналізовано становлення в історичній ретроспективі наукової бази імперської ідеологї Росі. Висвітлено формування українського та російського етносів. Обгрунтовано прадавність етнічних прочесів на землях Украӥни. Розкрито зміст основних дискусійних питань, які вплинули на зародження імперської ідеології Росї̈, а також сучасні прояви імперської політики Росії щодо України

Ключові слова: імперська політика Росї,, наукова база імперської ідеології, етнотворчі прочеси на землях України, сучасні прояви імперської політики.
Постановка проблеми. Сьогодні, як ніколи раніше, у весь зріст постало питання про історичні корені становлення взаємостосунків України та Росії. Події «Гібридної» війни, анексія Криму, бойові дії у Донбасі всьому світу продемонстрували агресивну політику й ідеологію «русского мира», спроби агресивного північного сусіда вернути Україну під свій безпосередній вплив, стати на заваді руху нашої країни до кращих зразків цивілізаційного розвитку людства. Як зароджувалася та визрівала імперська ідеологія та політика Росії в історичній ретроспективі, які її сучасні прояви - це надзвичайно актуальні питання для сучасного розвитку української держави, її становлення у світовому співтоваристві, а також успішному протистоянні агресії північного сусіда.

Аналіз останніх досліджень і публікацій. Питання порушеної нами теми досліджували В. Хвойка [2], В. Петров [3], В. Смолій та О. Гуржій [6] та інші. Увагу цьому питанню приділено у праці М. Костомарова «Книга битія українського народу» [9].

Автор статті ставить за мету дослідити витоки та шляхи розвитку імперської політики Росії щодо України.

Виклад основного матеріалу. Одним із наріжних каменів зародження імперської ідеології Росії постало питання про походження українського етносу. Тривалий час панівною залишалася, а для певної частини російських істориків і нині залишається теорія про меншовартість українського народу, положення про те, що його державності взагалі не існувало. Обгрунтуванням цієї точки зору слугували праці сотень імперських істориків, з-поміж яких М. Карамзін, В. Соловйов, В. Ключевський, М. Шахматов. Варто зазначити, що чимало вітчизняних істориків також обстоювали таку ж точку 3ору.

Основні постулати такої позиції:

- заперечення взагалі існування українського етносу, а народ який жив на Україні - це спольщена частина російського етносу;

- український етнос існує, але з'явився на історичній арені наприкінці XIV або на початку XV ст.;

- Киїська Русь утворилася з Новгорода;

- український народ не мав своєї державності.

На догоду політикам імперської Росії розроблялися теорії домінування російського етносу на всьому просторі царської Росії, окремі історичні факти замовчувалися, інші трактувалися відповідно до пануючих доктрин. Відбулася міфологізація історії східних слов'ян, де на перший план виступав російський народ. Визначальну роль тут відіграло релігійне питання. Православна віра із середини XIX ст. стає державною ідеологією, інструментом насадження головних напрямів імперської політики.

У підсумку викристалізувалися висновки, доктрини, які володіли i, на жаль, володіють умами переважної більшості громадян Росії. Основні $з$ них:

у царські часи: насадження політики формування народу великої і неділимої Російської імперії, а відтак заперечення будь-яких точок зору про особливість розвитку народів національних окраїн. Для України насаджувалися теорії меншовартості, малоросійщини. Заборонялися прояви автономії, мова, культура;

- у радянські часи - політика нівеляції національних відмінностей, створення єдиного економічного простору, який сталевими тросами зв'язував національні окраїни в єдине ціле, формування єдиного радянського народу, 3 домінантною позицією російської культури, мови, 
ментальності. Цьому слугували могутні засоби масової інформації, література, кінематограф, наукові інститути тощо;

- у новітні часи - спроби відновити Союз через реанімацію економічного союзу нині вже незалежних колишніх радянських республік. Ідея стосується не лише економіки, а й безпекових питань, політики незалежних держав, які повинні діяти за єдине. І знову ж таки, і в СНД, Митному союзі провідне місце відводиться Російській Федерації.

Питання походження українського та російського етносів, становлення їх державності.

Тож де істина у наукових дискусіях? Як свідчать наслідки археологічних досліджень, праці істориків, беззаперечним $\epsilon$ той факт, що на сучасній території України стародавні люди з'явилися в епоху раннього палеоліту. Як і решта народів, що населяли територію нинішньої України, пройшли пізній палеоліт, коли склався антропологічний тип людини розумної мезоліт, неоліт, коли сформувався первісно-общинний лад; енеоліт, коли розквітла Трипільська культура; бронзовий вік $з$ його найважливішою ознакою переходом від матріархату до патріархату; ранній залізний вік, коли виникає родова община, яка згодом перетворюється на сусідську територіальну общину. Окремі племена об'єднуються в союзи споріднених племен, а $з$ часом зливаються в народність, що називається літописцями, багатьма істориками, як слов'яни, слов' янський народ, протослов'яни, «старі слов'яни» предки українського народу.

Тобто, субстратом (основним чинником), виникнення українського етносу був місцевий (автохтонний) елемент, що почав формуватися в неолітичній добі (новому кам'яному віці), що тривала від 5000 до 1800 р. до н.е. Основою його було осіле населення, що почало займатися хліборобством, приручило худобу. В результаті еволюційних процесів воно досягло значних результатів у своїй матеріальній культурі.

Чи не головною територією, де розквітла ця висока хліборобська культура неоліту було Середнє Подніпров'я. Розвивалася вона від 3500 р. до 1400 p. до н.е. і дістала назву Трипільської. На Південній Київщині, Черкащині віднайдено понад тисячу значних пам'яток трипільської культури, серед яких унікальні поселення біля сіл Майданецьке та Тальянки Тальнівського району, Доброводи Уманського району Черкаської області [15].

Жило хліборобське населення трипільської культури в постійних оселях, будувало прямокутні будинки, майже сучасного типу. Основним його заняттям було землеробство. Трипільці вирощували пшеницю, ячмінь, просо. Землю обробляли мотикою. До наших часів дійшло чимало керамічних виробів трипільців. Численні фігурки жінки, датовані тим часом, свідчать про поширення релігійного культу богині-матері.

Ми не виводимо українців безпосередньо від трипільців, водночас безумовний вплив ця культура мала на формування ознак етнічної спільності мешканців цієї території, що з'явилися пізніше, на їх культуру, вибір постійної території проживання, спільності господарського життя, психічного складу.

На формування українського етносу мала вплив смуга території, яка межувала 3 Чорним морем та лінією заселення слов'ян на межі Степу та Лісостепу, крайніми південними землями якої були нинішні міста Канів та Черкаси. За даними А. Спіцина і В. Сєдова, для східних слов'ян ця територія мала етновизначальні впливи.

Саме через цю смугу пройшло чимало древніх племен, насамперед, кочових із південних земель, а також вихідців з інших територій. Безумовно, їх життя, звичаї, традиції, зв'язки з порубіжним місцевим населенням значною мірою впливали на формування слов'янського етносу.

Першими племенами, що досягли Середнього Подніпров’я у І тис. до н.е., і відомості про які дійшли до нашого часу, були кіммерійці, згодом скіфи, пізніше сармати, алани, роксолани. Наймогутнішими серед номадів українських степів, безумовно, були скіфи, які утворили державу.

На прадавніх мешканців цісї території мали також вплив торгові зносини з грецькими містамидержавами, які тривалий час функціонували на причорноморських землях.

Зрозуміло, що всі ці чужоземні елементи мали певний вплив на формування прадавньої історії українського народу. Однак перебільшувати або ж вважати його вирішальним, як на це справедливо вказували М. Грушевський та I. Крип'якевич, а також сучасні історики П. Толочко та Б. Рибаков, не варто, оскільки всі ці племена не «залишили практично ніяких організаційних традицій на Україні». Це зауваження стосується і часу колонізації території південно-західной України, а також гунів, які витіснили попередників.

Історичні джерела виразно фіксують слов'ян лише $з$ середини 1 тис. н.е., коли вони з'явилися на історичній арені Європи як баготочисельна етнічна спільність. М. Грушевський, а за ним I. Крип'якевич, інші дослідники прямо пов'язують етногенез української народності з життям і діяльністю антів, їх держави. М. Грушевський пише, що «грецькі письменники VI-VII ст. н.е. називали антами українців». Далі він зауважує: «Це й були наші українські племена, що зайняли тоді все побережжя Чорноморське від Дністра до Азовського моря і вперве тут виступають в історичних джерелах окремо, під назвою Антів».

У V-VI ст. предки українського народу розселилися на значній території, яка нині належить Україні. Вони виступають в цей час як окрема слов'янська група під іменем антів. Однією з територій компактного розселення антів вчені називають землі Середнього Подніпров'я. Під наступом кочівників-аварів впала могутня держава антів. Історична арена українського прадавнього народу знову змістилася у глибину території на смугу лісів Поділля, Київщину, Чернігівщину, і найважливішою територією стало Середне Подніпров'я (в широкому розумінні цього терміна).

Тут, на прабатьківщині українського народу, виникають могутні племена: полян на Середньому Подніпров'ї, сіверян над Десною, древлян на південь від Прип'яті, уличів над Південним Бугом, дулібів над Західним Бугом та інші. Як вказує І. Крип'якевич, «під природні захистом ... далі від наступів кочівників, почало організовуватися нове життя». Тогочас відбувається розклад первісно-общинного ладу, триває майнове розшарування населення, що вплинуло на появу початкових форм державності. Ці процеси розпочалися ще в VI ст. у надрах антських племен і продовжилися з часом у східних слов'ян на нових територіях, зокрема на Середньому Подніпров

Іншим важливим чинником, який вплинув на поширення ідеї державності серед слов'янських племен, стала постійна боротьба з експансією сусідніх держав, а також кочівників. Найнебезпечнішими 3 них були Візантія та азіатські орди.

Третьою важливою передумовою зародження державотворчих процесів серед слов'ян став господарський розвиток, а також розгортання торгівельних зв'язків. Багаті природні умови 
лісостепової смуги давали змогу торгувати здобиччю iз далекими східними купцями, а також представниками західних земель. Особливу роль відігравали укріплені городища, яких з'являється чимало в цей час.

На основі племінної організації, яка створювалася під впливом цих чинників, з'являється своя влада, своє «князювання». Літописець: «У полян своє, у древлян своє, у дреговичів своє». На чільне місце виходить плем'я полян 3 його стольним містом Києвом центром торгівлі, а згодом і політичного життя. «Поляне, яже ныне зовомая Русь», стали консолідуючим центром об'єднання східнослов'янських племен в могутню ранньофеодальну державу Київську Русь. Державотворчі процеси племен, що увійшли в цю державу, мали значний вплив на формування української народності, її культури, мови, побуту та звичаїв.

У трактуванні етногенезу українського народу серед вчених-істориків панують два погляди: автохтоністичний та міграційний. Прихильники першого вважають, що визначальну роль в утворенні українського народу, його розвитку, відіграли найдавніші мешканці території, які еволюціонували, вбираючи традиції, зміцнюючи спадкоємні зв'язки. Прихильники цієї тези вважають, що для історії українського народу міграційні процеси, переселення не відігравало значної ролі. Яскравим представником цієї течії був В. Хвойка, що розглядав етнічний розвиток середньо-дніпровського населення як єдиний поступовий процес від кам'яного віку до середньовіччя. Друга частина вчених, навпаки, вважає, що для історії українського народу вирішальними були міграційні процеси, рух населення. До таких вчених належить О. Шахматов, який виводив початок українського народу 3 Прибалтики через Подунав'я на Середнє Подніпров'я. Відомі погляди О. Соболевського та М. Погодіна, які вважали, що після монголо-татарської навали населення Середнього Подніпров'я було винищене або витіснене на північно-східні землі і на їх місце прийшли вихідці з Галичини.

Отже, цілком закономірним і логічним $\epsilon$ включення прадавнього етапу історії України до безпосереднього виникнення та розвитку українського народу. Мова тут не йде про визначення якихось особливих ознак нашого народу чи його винятковості тим, що доповнюється його історія прадавніми часами. Идеться про встановлення історичної правди.

Про що свідчать приведені беззаперечні історичні факти? На нашу думку про таке:

- український етнос один із найдавніших на європейських теренах і початки його формування належать до найдавніших часів. На землях України формувалася прабатьківщина східних слов'ян;

- виникнення перших державних формувань датується часом утворення державності антів та дулібів;

- ядром виникнення і функціонування Київської Русі стали племена, племінні союзи, які сформувалися на українських землях. Саме ця держава впродовж майже п'яти століть відігравала вирішальну роль в європейській політиці.

Дискусійні проблеми щодо питань, які вплинули на зародження імперської ідеології Росії.

Тривалий час і до нині залишається цілий ряд питань, які мають дискусійний характер у наукових колах, однак на угоду тим чи іншим політикам набувають і політичного забарвлення. Згадаймо хоча $б$ фразу В. Путіна, що кримський Херсонес має для
Росії сакральне значення. Зазначимо, що висвітлюються ці питання інколи $з$ діаметрально протилежної точки зору, попри те, що автори посилаються на одні й ті ж джерела (Несторова «Повість временних літ»).

Найголовнішими дискусійними питаннями, на нашу думку, є такі:

- включення чи не включення прадавнього етапу формування українського етносу до безпосередньої його історії. Це питання є ключовим для визначення шляхів походження українського народу, його окремішності;

- витоки зародження державності східних слов'ян, роль українського етносу у цьому процесі;

- етимологія термінів «Русь». «Росія», «Україна»;

- версії походження Давньої Русі;

- тривалість та наслідки монголо-татарського іга на землях України та Московії;

- окремішність розвитку українських земель в литовську та польську добу історії;

- утворення та діяльність Української держави в середині XVII ст.

- Переяславська рада та березневі статті 1654 року;

- позиція Росії в часи Руїни;

- політика Петра I та Катерини II щодо України;

- релігійний фактор у формуванні комплексу «молодшого брата»;

- формування комплексу «малоросійщини» тощо.

Це лише окремі дискусійні питання, які носять глобальний теоретичний характер. Однак їх з'ясування і вирішення певним чином екстраполюються на сучасний стан відносин між Україною та Росією.

Актуальність розв'язання дискусійних питань вимагає спільних зусиль, більш активної позиції українських істориків на міжнародній арені, зокрема:

- визнання міжнародною спільнотою особливого геополітичного становища України між Свропою в Євразією;

- утвердження незалежного розвитку України у напряму до кращих зразків світової цивілізації;

- необхідність подолання імперських амбіцій нинішніх керівників Російської Федерації, перегляд міфологем щодо взаємин між Україною та Росією.

Сучасні прояви імперської політики Росії щодо України

Анексія Росією Криму, збройний конфлікт на Південному Сході України засвідчили продовження імперських зазіхань агресивного сусіда, лідери якого ностальгують за утвердженням гегемонії на пострадянському просторі. 3 кінця 1990-х рр. прояви цих зазіхань яскраво проявилися в Придністов'ї, Абхазії та Південній Осетії. Не отримавши гідної оцінки міжнародної спільноти, Російська Федерація відчула свою безкарність, вседозволеність. Результатом цього стали події 2014 р. на території України.

Сценарій розгортання подій відпрацьований до деталей:

- нагнітання через засоби масової інформації як російськими, так і власними, представниками проросійських політичних партій та громадських організацій невдоволення місцевим керівництвом із боку населення;

- використання ностальгічних настроїв за великим Радянським Союзом із його стабільністю, хоча й бідністю, домінантою на значній частині карти світу;

- використання протестних настроїв у громадян, які викликані погіршення економічного становища значної частини населення, що стали можливими в результаті грабіжницьких захоплень державної власності через ваучерну приватизацію, розпаювання 
земель, корупційних проявів у суспільстві, неминучими у первинному накопиченні капіталу;

- сприяння сепаратиським проявам серед населення невдоволених автономних чи напівавтономних формувань, яким надсилалася відповідна матеріальна допомога аж до озброєння. Так відбувалося у Придністров $і ̈$, населення якого не сприймало шлях Молдови до великої Румунії; Абхазії, населення якої в основному жило за рахунок зв'язків 3 Росією і не сприймало курс Грузії на дистанціювання 3 північним сусідом. Дещо іншою була ситуацію у Криму на початку 1990-х рр. Тут також домінували сепаратистські настрої, що призвело до значного загострення з Україною, однак взаємостосунки вдалося уладнати через надання Криму широкої автономії. Важливим фактором тут стала наявність кримсько-татарського населення.

Подальшим розгортанням цього сценарію були такі елементи:

- допомога у проведенні протестних акцій, медійний супровід у власних засобах масової інформації та через активний вихід на закордон. Широко використовувався той факт, що російська інформаційна мережа практично повністю покриває суверенний простір кожної із держав;

- сприяння у формуванні сепаратистських органів самоуправління, які проголошували необхідність виходу зі складу держав. Проголошення необхідності й проведення референдумів;

- надання економічної, політичної та військової допомоги новоутвореним формуванням.

Такі сучасні прояви імперської політики Росії щодо держав сусідів. Однак корені такої політики сягають глибокої давнини. Вони потребують грунтовного наукового осмислення, врахування у розробці стратегії й тактики сучасної національної державної політики, проектування на перспективу взаємовідносин.

\section{Список використаної літератури та джерел:}

1. Украӥнська народність: нариси соиіально-економічноі і етно-політичної історії. - К. : Наукова думка, 1990.

2. Хвойка В. Древние обитатели Поднепровья и их культура в доисторические времена / В. Хвойка. - К., 1913. 3. Петров В. Походження українського народу / В. Петров. - К., 1992.

4. Дашкевич Я. Основні етапи етнічної історії українців / Я. Дашкевич. - К. : Родовід, 1991. Начіональна свідомість украӥнців на зламі XVI-XVII cm. - К. : Наука культура. - 1993. - Bun. 26-27. - C. 44-53.

5. Гуслистий К. До питання про утворення української наиї̈ / К. Гуслинський. - К:, 1967.

6. Смолій В. Як і коли почала формуватися украӥнська начія / В. Смолій, О. Гуржій. - К:, 1991.

7. Бромлей Ю. Очерки территории етноса / Ю. Бромлей. - M., 1983

8. Венелин Ю. О споре между южанами и северянами на счет их россизма / Ю. Венелин. - СПб., 1832.

9. Костомаров М. Книга битія українського народу / М. Костомаров. - К. ; Львів, 1921.

10. Рыбаков Б. Новая концепция предистории Киевской Руси / Б. Рыбаков. - М. : История СССР, 1984. - № 1-2. 11. Толочко П. Древняя Русь. Очерки сочиальнополитической истории / П. Толочко. - К., 1987.

12. Шахматов А. Древнейшие судьбы русского племени A. Шахматов. - Пг, 1919.

\section{References:}

1. Ukrainian nationality: Essays on socio-economic and ethno-political history. -K.: Naukova Dumka, 1990.

2. Khvoika V. Ancient inhabitants of the Dnieper region and their culture in prehistoric times. -K .: 1913.

3. Petrov V. Origin of the Ukrainian people. - K.: 1992
4. Dashkevich Y. The main stages of ethnic history of Ukrainians. -K.: Rodovid, 1991. National consciousness of Ukrainians at the turn of the sixteenth and seventeenth centuries. -K .: Science and culture. - 1993. - Issue 26-27. - P. 44-53.

5. Guslichy K. On the formation of the Ukrainian nation. - K.: 1967

6. Smolii V., Gurzhii O. How and when the Ukrainian nation began to emerge. - K.: 1991.

7. Bromley Yu. Essays on territory of the ethnic group. - M.: 1983;

8. Venelin Y. About the controversy between the southerners and the northerners on their attitude towards Russians. -St. Petersburg.: 1832;

9. Kostomarov M. The book of the existence of Ukrainian people. - K., Lviv. 1921

10. Rybakov B. A new concept of the prehistory of Kiev Rus. M .: History of the USSR, 1984 - №. 1-2;

11. Tolochko P. Ancient Rus. Essays on socio-political history. - K.: 1987;

12. Shakhmatov A. The most ancient destinies of the Russian tribe. - Pg.: 1919.

A.Chaban

\section{SOURCES AND WAYS OF DEVELOPMENT OF RUSSIAN EMPIRE POLICY ON UKRAINE}

Based on a large number of historical research and modern political science works, the proposed article analyzes the formation of the scientific base of the imperial ideology of Russia in the historical retrospective, analyzes the question of the formation of Ukrainian and Russian ethnos, states the ancient nature of ethnic processes on the lands of Ukraine, and highlights the content of the main discussion issues that have influenced the emergence of the imperial ideology of Russia, and it also highlights contemporarymanifestations of Russia's imperial policy towards Ukraine.

Today, as never before, the question of the historical roots of the emergence of relations between Ukraine and Russia has been brought up. The events of the "hybrid" war, the annexation of the Crimea, war acts in the Donbas, the attempts of an aggressive northern neighbor to return Ukraine to its direct influence, to stop the movement of our country to the best examples of civilization development of mankind demonstrated the aggressive policies and ideology of the "Russian world" to the whole world.

The advent and development of Russia's imperial ideology and politics in the historical progression, its current manifestations are extremely pressing issues for the modern development of the Ukrainian state, its formation in the world community, and also the successful opposition to the aggression of the northern neighbor.

It is concluded that Russia's annexation of the Crimea, an armed conflict in the south-east of Ukraine, confirmed the continuation of the imperial intentions of an aggressive neighbor whose leaders are nostalgic for asserting hegemony in the post-Soviet space. Since the end of the 90s, manifestations of these attacks have been manifested in Transnistria, Abkhazia and South Ossetia. Without proper reaction from the international community, the Russian Federation felt its impunity, permissiveness to do as they will. The result of this was the events of 2014 on the territory of Ukraine. The roots of this policy date back a long way. They require deep scientific reflection, consideration in the development of the strategy and tactics of modern national public policy, and planning future relations.

Key words: the imperial policy of Russia, the scientific base of imperial ideology, ethno-forming processes on the lands of Ukraine, modern manifestations of imperial politics. 